\title{
English - the torch of life: reflections on the Newbolt Report from an ITE perspective
}

Article

Accepted Version

Roberts, R. (2019) English - the torch of life: reflections on the Newbolt Report from an ITE perspective. English in Education, 53 (3). pp. 211-222. ISSN 0425-0494 doi:

https://doi.org/10.1080/04250494.2019.1657772 Available at https://centaur.reading.ac.uk/86083/

It is advisable to refer to the publisher's version if you intend to cite from the work. See Guidance on citing.

To link to this article DOI: http://dx.doi.org/10.1080/04250494.2019.1657772

Publisher: Wiley-Blackwell

All outputs in CentAUR are protected by Intellectual Property Rights law, including copyright law. Copyright and IPR is retained by the creators or other copyright holders. Terms and conditions for use of this material are defined in the End User Agreement.

www.reading.ac.uk/centaur

\section{CentAUR}


Central Archive at the University of Reading

Reading's research outputs online 


\title{
English - the torch of life: reflections on the Newbolt Report from an ITE perspective
}

\begin{abstract}
This article reflects on how English as a school subject was positioned in the seminal paper 'The Teaching of English in England', otherwise known as The Newbolt Report (1921), and its relationship with current government policy in England. The questions regarding the content and purpose of English as a subject that arise from the report are used as a lens to consider the challenges that are presented in the initial training year for Secondary English teachers, nearly a century since its publication.
\end{abstract}

\section{Introduction}

As I sit down to consider the content of university teaching for next year's cohort of beginning English teachers, I am struck (as I am every year) by how much time I spend grappling with what English is. This in part is, I feel, to do with the 'quicksilver' (Dixon, 1969, p. 1) nature of English as a subject. Accordingly, we spend time at the beginning of the PGCE considering the nature of English before beginning to dissect how one might begin teaching it. When The Teaching of English in England (Newbolt, 1921) (The Newbolt Report hereafter) was published, English was a prepubescent subject; the report made efforts to distance English from Classics, and stressed its importance as a unifying discipline that should be at the heart of English schooling. Yet some of the central proposals (and criticisms) of the way in which 
English was taught (and teachers trained) sound very familiar to contemporary discourse around the teaching of English in the twenty-first century. Comparing these proposals to the current secondary English curriculum, as conceived in the National Curriculum (2013), throws some light on how the positioning of English as a subject influences the content of a PGCE course and can present problems for the beginning English teacher in their growing professional identity.

\section{Newbolt, the National Curriculum, and the importance of English}

Sir Henry Newbolt (1862-1938) was a late Victorian/early Edwardian writer of imperialist, heroic poetry (Bright, 1990; Goldie, 2013). Terry Eagleton dismissed him as a 'minor jingoist poet and perpetrator of the immortal line "Play up! Play up! And play the game!"' (Eagleton, 1996, p. 25). It is fair to say that he is best remembered today, if at all, for the poem from which the line is taken: 'Vitai Lampada'. The refrain is a call to arms, linking the team spirit conjured by a cricket game and the sense of duty to bolster the bravery of a soldier in war. The poem is shot through with imperialism (the 'her' of the final verse a Britannia figure):

Every one of her sons must hear,

And none that hears it dare forget.

This they all with joyful mind

Bear through life like a torch in flame,

And falling fling to the host behind -

'Play up! Play up! And play the game!' (Newbolt, 1892) 
In Newbolt's vision, the role of school is to mould boys into patriots, ready to die for their country. If it is taught at all today, it is generally as a counterpoint to Owen's 'Dulce et decorum est' (Teachit, 2008). Infusing school-boy cricketing imagery with the 'sodden red' of spilt army blood, Newbolt captures a vision of unifying patriotism instilled via education. This is a tradition that must be passed on 'to the host behind'. The image of carrying and handing over a 'torch' encapsulates Newbolt's personal philosophy (Bright, 1990), also embodied in his report: English is the torch which will light the way for the nation: '[English is] the channel for formative culture for all English people' (Newbolt, 1921, p. 12).

Newbolt's report refers to Matthew Arnold's concept of culture uniting classes (Arnold, 1869/2006), arguing that education is the 'way to bridge the social chasms which divide us' (p.6). Similarly, twenty-first century teachers in England might recognise the allusion to Arnold in the current National Curriculum (NC) which states that its aim is to ensure that it 'introduces pupils to the best that has been thought and said' (Department for Education, 2013, p. 6). The connection between the importance of English and its relation to cultural capital is central to the argument that The Newbolt Report makes:

To every child in this country, there is one language with which he must necessarily be familiar and by that, and by that alone, he has the power of drawing directly from one of the great literatures of the world (p.13).

The significance of English as a subject is echoed in current NC: 'English has a preeminent place in education and in society' (Department for Education, 2013, p. 3). The capacity to civilise may have overtones of Empire and colonialism which seems 
to evoke what Young calls 'powerful knowledge' (Young, 2014). For English, this can be problematic, as I will address in a later section of this article.

Issues with canonicity aside, the Newbolt Report distinguishes the subject from that of Classics, which is described as 'distracting' (p.11) since having to learn Greek and Latin acts as a barrier for children not able to engage immediately with, and therefore understand, texts in the way that they can when they are in their native tongue. There is within this aspect of the report's central proposal a conceptualisation of the process of learning that is more aligned to a constructivist perspective of English:

It must be realised that education is not the same thing as information, not does it deal with human knowledge as divided into so-called subjects. It is not the storing of compartments in the mind, but the development and training of faculties already existing. It proceeds, not by the presentation of lifeless facts, but by teaching the student to follow the different lines on which life may be explored and proficiency in living may be obtained. It is, in a word, guidance in the acquiring of experience. (p.8)

It is for this reason that we might describe the report's view as 'forward-looking' (Fleming \& Stevens, 2015, p. 4); a contemporary account stated that 'the whole of the report is a protest against the utilitarian view of education' (The Manchester Guardian, 1921). There is, as Davison and Daly (2014) suggest, a contradiction in the positioning of English between 'notions of correctness, cultural heritage and a belief in the humanising nature of literature' (p. 23). These tensions have certainly not disappeared over the last 98 years and, the regular interventions from central government in terms of both content and pedagogy (Gibbons, 2017) can lead to unintended and undesirable practices, such as the ubiquity of the Point, Evidence, Explanation (PEE) paragraph in pupils' analytical writing (Roberts, 2019). It is perhaps the importance of English as a subject that can be traced back to Newbolt's report that has led to a subject that is in constant ontological status, as I argue elsewhere (Roberts, Forthcoming). This makes starting a training course such as a 
PGCE a tricky prospect; how can a beginning teacher consider pedagogical approaches if she does not have a sure-footed foundation in her conception of what she is teaching to begin with?

\section{The purpose of English: Newbolt and the Cox Report}

Newbolt and his co-authors considered English to be the subject that could bring the nation together, arguing that it develops both mind and character (p.21). They were highly critical of an understanding of English that reduced the subject to functional 'commercial' (p. 21) interests, as 'English is not merely the medium of our thought, it is the very stuff and process of it' (p. 20). This positions English at the very heart of schooling, more than just another 'timetabled subject'. In addition, literature is 'a source of delight, a personal intimacy and the gaining of personal experience, an end in itself and, at the same time, an equipment for the understanding of life' ( $p$. 19). The report therefore specifies a number of different purposes of English:

- To bring unity through culture

- To development children's character

- To provide communication skills necessary for a productive workforce

- To enable access to all subjects

- To develop understanding and experience of life

These purposes are strikingly similar to the purposes of English identified in the Cox Report (DES and the Welsh Office, 1989):

- Personal growth

- Cross curricular 
- Adult needs

- Cultural heritage

- Cultural analysis

Whilst the Cox Report made clear these views of English were not the only view of English, and that they overlap, it is interesting to consider the purchase that Cox's models have had on our thinking of our subject. Research into English teachers' perceptions of the subject in relation to the models suggest that different models become more important at different times: 'personal growth' and 'cultural analysis' in the early 1990s (Goodwyn, 1992), then 'cultural heritage' (Findlay, 2010) more recently, possibly reflecting reactions to changing specifications.

A number of books aimed at English PGCE students ask their readers to consider their views of English in relation to Cox's models (Davison \& Daly, 2014; Fleming \& Stevens, 2015; Green \& McIntyre, 2011) and it is an exercise that I use with PGCE students myself. In the first university session, students are asked to consider:

- What is English?

- What is your own view of English?

- Why does English have a controversial status?

The discussions around these questions lead to the trainees composing their own view of English, which we revisit at different points in the course. The purpose of this exercise is to encourage trainees to consider the nature of the subject that they are going to teach and to be aware that their views of it (often influenced by their own experience of schooling and higher education) will influence how they understand 
what they do and the choices that they make as teachers. Beginning teachers' professional identity is fragile (Kelchtermans, 2009) and they may find some of their ideals challenged in different school contexts; it is therefore important for them to consider their values in English. This is connected to their motivation to become a teacher - assuming that most do so for at least partly altruistic reasons (Lortie, 1975).

\section{The 'content' of English: Newbolt and the National Curriculum}

It is possible to identify the seeds of what was to become the National Curriculum for English in the Newbolt Report (Doug, 2011). Newbolt identifies reading, writing, and speaking as core aspects of English. The inherent tension of English's purpose is suggested again in the proposal to teaching spoken language and Standard English (SE) as the report comments that 'the English people might learn as a whole to regard their own language with respect, and then with a genuine feeling of pride and affection... to maltreat it or deliberately debase it would be seen to be an outrage' (p.22), yet at the same time the report explicitly states that there should not be a 'suppression of dialect' in the teaching of SE, merely that it is 'desirable' for communication across the country (p.69).

A comparison of the expected content of the Ordinary Course (a precursor to the 'O' Level) listed in the Newbolt Report with the current Key Stage 4 NC for English suggests little change in the kinds of texts studied:

Ordinary Course: 'Two plays of Shakespeare must be read, and on of them the meaning of the text should be studied in detail. For general reading fifteen books are included, but students are not expected to answer questions on more than five. Eight of the fifteen books are novels, and not more than two of the five questions attempted may refer to these. Of the remaining seven books three are poetry (an anthology, selections from Browning and 
selections from Tennyson) and four are prose, the authors being Burke, De Quincey, Carlyle and Stevenson.' (pp. 179-180)

National Curriculum KS4: 'reading a wide range of high-quality, challenging, classic literature and extended literary non-fiction, such as essays, reviews and journalism. This writing should include whole texts. The range will include:

- at least one play by Shakespeare

- works from the 19 th, 20 th and 21 st centuries

- poetry since 1789 , including representative Romantic poetry' (Department for Education, 2013, p. 5)

Selections of fiction and non-fiction; Shakespeare; anthologies of poetry including nineteenth century poets: there is much similarity between the outlined 'content' envisaged by the Newbolt Report and the current NC. In addition, the report advocates fostering a love for reading, a stance advocated in the current NC: 'choosing and reading books independently for challenge, interest and enjoyment' ( $p$. 5). The report is critical of the mis-representation of the content of English lessons which are

....apt to assume that school lessons in literature are confined to the study of elaborately annotated texts of Shakespeare, and that school essays chiefly revolve upon vague and abstract themes like Patriotism and Moral Courage, with occasional but doubtful relief in the form of an essay on Football (p. 103).

Examples of the development of imaginative writing and drama utilised in lessons point to a more rounded understanding of English as a subject. Whilst the version of English represented in the Newbolt Report, like the current NC, cohere more with 'Cambridge' English, with a focus on the so-called 'Great Tradition', there is also a recognisable glimmer of a more 'progressive' London English within the document. From this perspective, there appears to be a consistency in the content of English between the Newbolt Report and the National Curriculum. However, as English is a subject built upon texts, the question of which texts that should be taught is a defining point, and one that seems to continue to preoccupy policy makers. How the NC directly informs text-choice in schools is beyond the scope of this article, but it 
does present the trainee English teacher with a complexity that is at the heart of our subject: the relationship between text and knowledge.

\section{The problem with 'knowledge' in training English teachers}

The Newbolt Report is quite scathing of both the quality of teachers and their preparatory training in the first decades of the twentieth century; although on this latter point it is somewhat contradictory in stating that 'the ideal teacher is born, not made' (p. 125), and also acknowledging that 'it is unfortunately true that methods of teaching English are so far little developed... English teaching.... Demands endless skill and resource, is too often thought a task which any teacher can perform' ( $p$. 113).

The difficulty lies in the tussle the report seems to have between pedagogy and subject knowledge. Lee Shulman's (1986) concept of Pedagogical Content Knowledge (PCK) is the intersection between the two; it is the lack of PCK in the training of English teachers that the report seems frustrated with. This, at least, has made some progress over the last one hundred years.

In relation to current teacher education, let us first consider the construct of the PGCE (for the purposes of this article, I am referring to university-led training courses). Typically, a PGCE course will consist of two key elements: the university taught sessions and school-based experience. Sometimes this is categorised (wrongly) as 'theory' and 'practice'; I am keen to convey to trainees at the beginning of the course that university sessions are not 'theory', which connotes a remoteness 
from the 'real-world' of what goes on in schools. Rather, the sessions provide the opportunity to engage with pedagogical approaches which can then be examined and practiced in the context of their school setting.

In 2016 the Department for Education published a Framework of Core Content for ITT (Department for Education, 2016); this was in response to the Carter Review (2015) as a way of addressing 'variability in ITT content across the system' (p. 3). The framework is generic and applicable to all phases and types of ITT and should work 'alongside' the existing Teachers' Standards, setting out 'the key knowledge, practice and behaviour that providers must ensure trainees are demonstrating in order to satisfy themselves that the Standards are being met' (p. 6). Whilst there has been some criticism of the notion of the development of a core content for ITT (Cruice, et al., 2017), the DfE's guidance is decidedly generic - it focuses on demonstration of understanding and knowledge through performance. For example, Teachers' Standard 3 states that:

Trainees should be conversant with a range of effective subject-specific pedagogical approaches, and know how to address common pupil misconceptions in their subject(s). (Department for Education, 2016, p. 15)

The conception of subject knowledge as described in the Framework is a transmission model:

Providers should audit trainees' subject knowledge early in their training and make provision to ensure that trainees have sufficient subject knowledge to satisfy the standard by the end of their training. (ibid.)

The version of 'knowledge' presented here is of an empty/full vessel. This conception of knowledge does not align with the subject of English proposed in the Newbolt Report nor one to which I would personally subscribe. Knowledge in English is 
contextual and dynamic: 'the process of meaning-making is summoned into being in conversation... between readers or between students and their teachers' (Knights, 2018, p. 44). It is more than being able to recount the narrative of a novel or identify and define poetic devices; it may be more accurate to consider this 'process of meaning-making' as employing lots of different 'knowledges' (such as cultural or historical context) which are brought to bear when engaging with texts (Roberts, 2019), linked to personal experience (Eaglestone, 2019).

The problem with 'knowledge' for an English trainee is partly rooted in the way in which it is framed through such activities as 'subject knowledge audits' at the beginning of the course, as it implies that knowledge of a text (or author, or genre, or era) is primarily about familiarity. There are several layers of textual knowledge that need to be elucidated: knowledge of the text itself (i.e. through having read it); knowledge of its context (historical, cultural, authorial, inter-textual relationships, interpretations or transformations of the text); critical perspectives of the text (both historical and contemporary) and affective responses to the text. The complexity of these 'knowledges' is belied by the simplistic notions suggested in government policy.

This therefore presents a challenge to identifying PCK for English teacher training courses. Pedagogy for other subjects may conceive knowledge as a more straightforwardly transmission model. The 'content' of English curricula is subject to regular change; this means that identifying 'content' in PCK for English is problematic (Doecke \& Mead, 2018). 
The content of the PGCE English course 2018-19 at my own institution consists of the following sessions:

- Introduction to English

- Models and approaches to the teaching of English

- The National Curriculum and planning

- Planning and progress

- Teambuilding, group work and working with Teaching Assistants

- Learning from observing

- Learning through talk

- Teaching reading

- Developing a community of readers

- The English curriculum and Seminal World Literature

- Behaviour for learning in English

- Teaching writing

- Reading as a writer; writing as a reader
- Teaching grammar

- Differentiation in English

- The 'secrets' of teaching and learning in English

- Assessment for learning in English

- Teaching poetry

- Working with dyslexic pupils in English

- Assessment of learning in English

- Teaching Shakespeare

- Teaching plays in English

- Teaching essay writing in English

- Teaching EAL pupils in English

- Media in English

- Spoken language

- Creativity in English

- Approaches to post-16 English

The content identified here appears to be fairly typical of the provision compared to other institutions, see for example the University of Leicester (2019). Although the sessions are updated, added to or modified each year, the topics largely remain the same. (It is unlikely that any English teacher training course would not include a 
session on approaches to teaching Shakespeare.) My rationale for their inclusion in the course is largely driven by what is commonly taught in schools - that is to say the curriculum.

\section{The curriculum in English and its relationship to the canon}

The current emphasis on teaching a curriculum which is 'knowledge-rich' (as advocated by E.D. Hirsch (1999)) is evident in both wider educational discourse and in the thinking of current ministers of education (Gibb, 2015) and Ofsted (Spielman, 2018). If the curricula of schools in England (with the exception of academies) is set by the NC, the general content for English is similar to the first incarnation of the NC introduced in 1988, with Reading, Writing and Spoken Language at the heart of what English lessons teach (see Roberts, Forthcoming, for a more detailed analysis of the current NC for English). If we have taught descriptive writing in English for the last 100 years (albeit with a range of different emphases and focuses) it could be argued that the 'content' is unchanged. The same cannot be said in relation to literature. A key criticism of 'powerful knowledge' from an English perspective concerns the issues it raises with regards literary canon. If teaching 'powerful knowledge' is, in part, to do with equity of access to rarefied texts, then much significance is given to the specific texts that are taught. As Doecke and Mead (2018) argue, Shakespeare not does provide the same kind of universal truths that Newton does.

The Newbolt Report positioned English as a subject to unify through culture (Bhattacharyya, 1991). This process must necessarily be exclusive. The report does not provide a list of approved texts, but there is a clear hierarchy of worthy literature that should be taught (p.84). English writers (and two Scots) are liberally 
referred to throughout: Dickens, Shakespeare, Wordsworth, De Quincey, Chaucer, Bunyan, Milton, Eliot, Tennyson, Scott, Browning, Stevenson, Kingsley. A modern criticism of this would be its lack of diversity (there is only one woman and no writers of colour). The limitations of only teaching this kind of literature has been explored through student-led movements such as 'Why is my curriculum white?' (Peters, 2015), with a number of universities 'decolonising' their curriculum (Kennedy, 2017). Children need to make a connection with the literature that they read (Alsup, 2015). The Newbolt Report acknowledges this:

\begin{abstract}
We do not suggest that only the recognised English classics should be included... The teacher who means the effect of this work to be lasting will start from what the children themselves enjoy, recognising that even though what they read may be rubbish, their being willing to read at all is a definite asset. If he sets about it in the right way, he will soon be able to wean them from the merely mawkish or blood-curdling to read wholesome boys' and girls' books, simple ballads, and so onwards, but if he takes the line that to read trash is a moral offence, and if he coerces rather than persuades, he will be doing them a mischief in spite of his good intent. (p. 84)
\end{abstract}

There is an evident tension between fostering a love for reading and developing a reading of texts because they are improving. It raises issues of class, amongst others: are these texts lauded because they embody middle class values? In a multi-cultural modern Britain we are more aware of the assumptions of homogeny (Nigerian novelist Chimamanda Adichie's Ted Talk (Adichie, 2009) provides an eloquent explanation of why the dominance of a single kind of story or perspective in children's literature can affect how children see themselves in the world).

It could be argued that the Personal and Professional Conduct section of the Teachers' Standards, against which trainee teachers are assessed, reinforces liberal values:

- Showing tolerance of and respect for the rights of others

- Not undermining fundamental British values, including democracy, the rule of law, individual liberty and mutual respect, and tolerance of those with different faiths and beliefs (Department for Education, 2011, p. 14) 
The Teachers' Standards do not define 'British values', other than by stating elements that teachers must not undermine democracy, law, liberty, respect and tolerance. What makes these values particularly British is not clear, other than to suggest that the purpose of education is to instil a sense of cultural and national belonging, a very Newboltian sentiment.

Discussion around text choice for beginning English teachers is therefore crucial: which texts should be taught and why? Should the choice of literary texts (including children's literature) take into account the children who are being taught in terms of demographics? Given the narrowing of the texts taught at KS4 (Bleiman, 2018), greater freedom could be exercised at Key Stage 3, as the NC includes 'seminal world literature' (Department for Education, 2013, p. 4). Yet even here there is an assumption in the NC about texts' worthiness, as children should be taught works that are 'high-quality' (ibid.). What counts as 'high-quality' and who decides? With regards contemporary fiction, does this mean only novels written by established authors should be taught? Or ones that meet a diffuse set of literary standards or winners of literary prizes? A model of English as predominantly 'cultural heritage' risks crowding out the space to develop an interest in or love of contemporary texts.

The university seminars that I teach are not didactic in the sense that trainees are told what to teach and how to teach it - far from it. As Sue Dymoke expresses in her reflection of the English PGCE, my aim is for trainees to critically engage

...themselves and their pupils in debates about the rich, diverse and constantly evolving nature of the subject and the roles of its speakers, writers, readers, creators and viewers within an increasingly global society. Trainees need to continue to develop their critical thinking about the subject beyond the confines of the taught university subject session, both through their independent study and discussions with co-tutors in their placement schools 
about the teaching strategies, specifications and interpretations of the national initiatives that their departments have chosen to adopt. (Dymoke, 2004, p. 46)

University sessions are research-informed, provide opportunity to discuss, debate and reflect on school experience and practice some approaches and are taught by school-based colleagues as well as myself. Trainees' learning is a complex combination of reading, discussing, observing, experimenting, questioning - so that they can become professionals, not technicians.

\section{The role of the English teacher: are we all Newboltians?}

The Newboltian English teacher needs 'exceptional gifts' (p. 125) to bring texts to life for his pupils (p. 85), whose job is twofold: 'to teach the pupil to speak and write clearly, forcibly and correctly; secondly, to foster a love of literature' (p. 124). The very teaching of literature, this implies, is enough to teach unity, understanding and character. Newbolt's English teachers are literary guides:

...who will not come between their pupils and the author they are reading, but will stand by them sympathetically, directly or moderating the impact of the new experience upon their minds. (p. 24)

The relationship between text, teacher and pupil described in the Newbolt Report is much closer to an understanding of English as a process of meaning-making via discussion. This is conceived as a capacity for an 'artistic feeling' (p. 181), and personal characteristics of 'sympathy and humour' (p. 127). The combination of passion for literature and desire to share this through dialogue seems to draw on both affective and aesthetic responses to texts, the latter requiring

... a high level of substantive and disciplinary knowledge of literature. And it requires a lot for school teachers in terms of professional trust and autonomy at the level of pedagogy where the general level of pupils' prior educational and literary experience also needs to be considered, in conjunction with the selection of texts according to aesthetic merit, and subjectspecific pedagogic approaches in the classroom. (Seghal Cuthbert, 2019, p. 12) 
Given the diversity of English PGCE students' subject backgrounds (Fitzgerald, et al., 2012), and the constant pressure to change our subject applied by outside forces (Bleiman, 2018), the space that university sessions can provide for beginning English teachers is the starting point for a career-long engagement with the conversation that is English.

\section{Conclusion}

As we approach the centenary of the Newbolt report's publication, it is striking how relevant it still feels: the questions that it raises regarding English's importance as a subject; how its purpose must be more than functional; the problematic nature of its content and how knowledge is conceptualised. All of these questions are pertinent to the discipline in the twenty-first century and, if a key aim of a PGCE course is to critically engage with these fundamental questions, the Newbolt report provides an salient starting point for beginning English teachers to consider their subject, their relationship to these debates and therefore their approach to English teaching.

Newbolt's vision of a country brought together through the study of literature may not have come to fruition (at least in the way in which he envisioned), and there is an ongoing need for beginning English teachers to think about and critique their subject that is full of tensions, particularly in times of political interference and policy change. Yet I am hopeful each time I interview a prospective student; their desire to pass on their love of literature, interest in language, compulsion to make a difference to children's lives is inspiring - theirs is the torch of English to light the way. 


\section{References}

Adichie, C., 2009. www.ted.com/talks. [Online]

Available at:

https://www.ted.com/talks/chimamanda adichie the danger of a single story?utm campaign=ios-share\&utm medium=social\&source=email\&utm source=email [Accessed 9th April 2019].

Alsup, J., 2015. School, A Case for Teaching Literature in the Secondary. New York: Routledge.

Arnold, M., 1869/2006. Culture and Anarchy. Oxford: Oxford World's Classics.

Bhattacharyya, G., 1991. Cultural Education in Britain: from the Newbolt Report to the National Curriculum. Oxford Literary Review, 13(1), pp. 4-19.

Bleiman, B., 2018. The Changing Picture of School English. In: R. Eaglestone \& G. Marshall, eds. English: Shared Futures. Cambridge: D.S. Brewer, pp. 7-15.

Bright, M., 1990. Remembering Sir Henry Newbolt: An Essay and Bibliography.

English Literature in Transition, 1880-1920, 33(2), pp. 155-178.

Byrne, V., 2019. Making Sense of ITE: A Trainee Reflects. Teaching English, Issue 19, pp. 60-64.

Carter, A., 2015. www.gov.uk/government/uploads/. [Online]

Available at:

https://www.gov.uk/government/uploads/system/uploads/attachment data/file/39995 7/Carter Review.pdf

[Accessed 9th April 2019]. 
Cruice, M., Smith, L., Cliff-Hodges, G. \& Roberts, R., 2017. Tean Store House. [Online]

Available at: https://www.cumbria.ac.uk/media/university-of-cumbria-website/contentassets/public/education/documents/research/tean/Cruice,-Smith,-Cliff-Hodges,--

$\underline{\text { Roberts.pdf }}$

[Accessed 8th April 2019].

Davison, J. \& Daly, C., 2014. Learning to Teach English in the Secondary School: A companion to school experience. 4th ed. Abingdon: Routledge.

Department for Education, 2011. www.gov.uk/government/publications/teachersstandards.. [Online]

Available at: https://www.gov.uk/government/publications/teachers-standards. [Accessed 9th April 2019].

Department for Education, 2013. www.gov.uk. [Online] Available at: https://www.gov.uk/government/publications/national-curriculum-inengland-framework-for-key-stages-1-to-4

[Accessed 6th April 2019].

Department for Education, 2013. www.gov.uk. [Online] Available at: https://www.gov.uk/government/publications/national-curriculum-inengland-english-programmes-of-study

[Accessed 9th April 2019].

Department for Education, 2013. www.gov.uk/government/publications/nationalcurriculum-in-england-english-programmes-of-study. [Online] Available at:

https://assets.publishing.service.gov.uk/government/uploads/system/uploads/attach 
ment data/file/244215/SECONDARY national curriculum - English2.pdf [Accessed 5th April 2019].

Department for Education, 2016. https://www.gov.uk/government/publications/initialteacher-training-government-response-to-carter-review. [Online]

Available at: https://www.gov.uk/government/publications/initial-teacher-traininggovernment-response-to-carter-review

[Accessed 9th April 2019].

DES and the Welsh Office, 1989. English for ages 5-16 (The Cox Report), London: HMSO.

Dixon, J., 1969. Growth Through English: A Report Based on the Dartmouth Seminar 1966. Hudderfield: National Association for the Teaching of English/Oxford University Press.

Doecke, B. \& Mead, P., 2018. English and the knowledge question. Pedagogy, Culture \& Society, 62(2), pp. 249-264.

Doug, R., 2011. The British schools' National Curriculum: English and the politics of teaching poetry from 'different cultures and traditions'. Journal of Curriculum Studies, 43(4), pp. 439-456.

Dymoke, S., 2004. Stemming the strategy flood tide in PGCE English. Education 313, 32(3), pp. 45-50.

Eaglestone, R., 2019. Literature: Why It Matters. Cambridge: Polity.

Eagleton, T., 1996. Literary Theory: An Introduction. 2nd ed. Oxford: Blackwell. Findlay, K., 2010. The Professional Identity of English Teachers in the Secondary School. Coventry, BERA. 
Fitzgerald, B., Smith, L. \& Monk, J., 2012. Celebrating creativity collaborateively: Inspiring PGCE English trainees to teach creative writing. English in Education, 46(1), pp. 56-69.

Fleming, M. \& Stevens, D., 2015. English Teaching in the Secondary School. 4th ed. Abingdon: Routledge.

Gibb, N., 2015. How E. D. Hirsch Came to Shape UK Government Policy. [Online] Available at: https://policyexchange.org.uk/wp-content/uploads/2016/09/knowledgeand-the-curriculum.pdf [Accessed 26th June 2018].

Gibbons, S., 2017. English and Its Teachers: A History of Policy, Pedagogy and Practice. Abingdon: Routledge.

Gilbert, F., 2019. Standard Practice? English Teaching and the Teachers' Standards. Teaching English, Issue 19, pp. 33-36.

Goldie, D., 2013. Archipelogic Poetry of the First World War. In: S. Das, ed. The Cambridge Companion to the Poetry of the First World War. Cambridge: Cambridge University Press, pp. 159-172.

Goodwyn, A., 1992. English teachers and the Cox models. English in Education, pp. 4-10.

Goodwyn, A., 2002. Breaking up is hard to do: English teachers and that LOVE of reading. English Teaching: Practice and Critique, 1(1), pp. 66-78.

Green, A. \& McIntyre, J., 2011. What is English?. In: A. Green, ed. Becoming a Reflective English Teacher. Maidenhead: Open University Press/McGraw-Hill, pp. 625. 
HM Government, 2016. A framework of core content for initial teacher training, London: Crown Copywright.

Kelchtermans, G., 2009. Who I am in how I teach is the message: selfunderstanding, vulnerability and reflection. Teachers and Teaching: theory and practice, 15(2), pp. 257-272.

Kennedy, M., 2017. www.theguardian.com/education. [Online]

Available at: https://www.theguardian.com/education/2017/oct/25/cambridgeacademics-seek-to-decolonise-english-syllabus [Accessed 9th April 2019].

Knights, B., 2015. English Studies: A Very Brief History. In: Masterclass in English Education. London: Bloomsbury, pp. 5-15.

Knights, B., 2018. Pedagogic Criticism: An Introduction. In: R. Eaglestone \& B. Marshall, eds. English: Shared Futures. Cambridge: D.S. Brewer, pp. 40-50.

Lortie, D., 1975. Schoolteacher. Chicago: University of Chicago.

McCallum, A., 2019. The Critically Literate Trainee. Teaching English, Issue 19, pp. $69-70$.

Newbolt, H., 1921. The Teaching of English in England, London: His Majesty's Stationery Office.

Peters, M., 2015. Why is My Curriculum White?. Educational Philosophy and Theory, 47(7), pp. 641-646.

Pike, M., 2003. The canon in the classroom: Students' experiences of texts from other times. Journal of Curriculum Studies, 35(3), pp. 355-370. 
Roberts, R., 2019. The Text's the Thing - isn't it?. Teaching English, Issue 19, pp. 29-32.

Roberts, R., Forthcoming. A ‘God-like Science’: English Teaching in Secondary

Schools. In: C. J. Hall \& R. Wicaksono, eds. Ontologies of English.

Reconceptualising the language for learning, teaching, and assessment. Cambridge: Cambridge University Press, p. Ch7.

Seghal Cuthbert, A., 2019. Literature as aesthetic knowledge: implications for curriculum and education. The Curriculum Journal, pp. 1-15.

Shulman, L., 1986. Those Who Understand: Knowledge Growth in Teaching. Educational Researcher, 15(2), pp. 4-14.

Smith, L., 2014. ICT for English in English ITE: An investigation into the ICT component of PGCE English courses. English in Education, 48(1), pp. 63-75.

Smith, L., 2019. 'We're Not Building Worker Bees.' What Has Happened to Creative Practice in England Since the Dartmouth Conference of 1966?. Changing English, 26(1), pp. 48-62

Smith, L. \& Spiteri, D., 2013. A Tale of Two Cities: A comparison of the PGCE Secondary English Programmes at the Universities of Bristol and Malta, with particular emphasis on the student teachers' school-based experience and the role of the mentor. English in Education, 47(3), pp. 213-228.

Spielman, A., 2018. www.gov.uk/government/speeches/. [Online] Available at: $\mathrm{HMCl}$ commentary: curriculum and the new education inspection framework. Retrieved from https://www.gov.uk/government/speeches/hmci- 
commentary-curriculum-and-the-new-education-inspection-framework [Accessed 9th April 2019].

Teachit, 2008.

https://r.search.yahoo.com/_ylt=AwrJS9MuY6dcFkIAnwoM34IQ;_ylu=X3oDMTByM Wk2OWNtBGNvbG8DaXlyBHBvcwMyBHZOaWQDBHNIYwNzcg-$/ R V=2 / R E=1554502574 / R O=10 / R U=h t t p s \% 3 a \% 2 f \% 2 f w w w . t e a c h i t e n g l i s h . c o . u k$ [Online]

Available at:

https://r.search.yahoo.com/ ylt=AwrJS9MuY6dcFkIAnwoM34IQ; ylu=X3oDMTByM Wk2OWNtBGNvbG8DaXlyBHBvcwMyBHZOaWQDBHNIYwNzcg-$\underline{\mathrm{RV}=2 / \mathrm{RE}=1554502574 / \mathrm{RO}=10 / \mathrm{RU}=\mathrm{https} \% 3 \mathrm{a} \% 2 \mathrm{f} \% 2 \mathrm{fwww} . \text { teachitenglish.co.uk\%2fa }}$ ttachments\%2f10520\%2fdulce-et-decorum-est-and-vitai-lampada.pdf/RK [Accessed 5th April 2019].

The Manchester Guardian, 1921. English the Bedrock of Liberal Education, Manchester: The Manchester Guardian.

University of Leicester, 2019. le.ac.uk/education/study/pgce/courses/english. [Online] Available at: https://le.ac.uk/education/study/pgce/courses/english [Accessed 9th April 2019].

Young, M., 2014. Knowledge and the Future School: Curriculum and Social Justice. London: Bloomsbury. 